for example, reveals that Stoppard has contributed to a range of film scripts that includes Schindler's List (1991) and Tim Burton's Sleepy Hollow (1999), while the "Miscellaneous" chapter includes Stoppard's role as a judge of the 1972 Times Anthology of Detective Stories, alongside Agatha Christie. Altogether, this book is an amazing work of bibliographic scholarship, and a welcome addition to any collection supporting literary research.Timothy Hackman, University of Maryland.

\section{E-books in Libraries: A Practical}

Guide. Eds. Kate Price and Virginia Havergal. London: Facet Publishing, 2011. 327p. paperback, $£ 49.95$ (ISBN 9781856045728). LC2010-671269.

Advertised as the first practical appraisal of e-books for library and information professionals, E-books in Libraries: A Practical Guide provides vital background information about e-books and examines a wide range of e-book-related practical issues in different library settings from business and pricing models, vendor selection, collection development, staffing and workflow changes to budgeting and finance, access management, promotion and engagement of readers, IT support, and OPAC display. This book aims to "bring together a selection of practical information, best practice and case studies which would be of assistance to library and information professionals who are managing collections of e-books... and those who are just beginning to dip their toes in the water."

As the Preface of this book states, even though e-books have been in existence for decades and added to library collections for years, there still has been a noticeable lack of published manuals on how libraries should handle e-books as a part of their collections. On one hand, this is caused by the fast-changing nature of the e-book market; on the other hand, no consensus yet has been reached about what types of digital objects should be termed "e-books." Given all the uncertainties, e-books still receive a great amount of attention because of the proliferation of distance learning, the increasing demand of 24/7 access, and the wide availability of mobile devices and e-readers. During this transitional period from print to electronic, most library and informational professionals are eager to get some sort of practical guidance. This book is designed to fill the gap.

E-books in Libraries is a collective work edited by Kate Price and Virginia Havergal, who are renowned scholars as well as experienced practitioners in the field of e-books. All pieces included in this collective work are contributed by librarianscholars or librarian-practitioners who have been engaging in the frontline work of e-book management from diverse library settings. Each piece draws upon the expertise and unique perspective of the contributors.

Following an introductory overview, the book is divided into six parts. Part I contains four chapters that broadly examine how e-books come to be and the distribution process. From a business perspective, the first article examines the major challenges faced by the publishing industry, primarily the costs of producing e-books. The second article provides practical guidance on vendor selection, content delivery method, and a comparison among different business and pricing models that are prevalent in the U.K. and U.S. markets. Attention also has been extended to patron-driven acquisition. Part I also touches upon the EU's "books2ebooks" or e-books on demand service, and how libraries should handle freely available Internet resources. Part II is devoted to e-book acquisition and collection development in three different library settings: public libraries, further education (FE), and higher education (HE). Many strategies are offered for coherent collection development, such as: how to benefit a diverse audience, including people with disabilities; how to ensure a value-for-money collection; budgetary management; and staffing and workflows. Part III focuses on the delivery process of e-books and how libraries can better guide readers with the discovery process. This 
part implies that the discovery process could be enhanced from three aspects: improving e-book visibility in OPAC displays; providing training sessions and other research support; and implementing better technical supports in terms of federated access management and intelligent user interfaces. A discussion of different e-readers currently available on the market is also included in this section. Part IV uses case studies and analysis to show how readers could be better engaged in using e-books in public library, FE, and HE settings. All three studies indicate that today's readers are more willing to use e-books, with the level of willingness highest among younger reader groups. Part V looks to the future; each contributor was asked to comment on two vital questions: "What needs to change before e-books become universally and easily read?" and "What will the e-book landscape look like in ten years' time?" The final and most useful part provides a range of helpful guidelines, reference materials, and practical tips to aid library and information professionals to find their way through the e-book maze.

In general, the editors of this book have done a great job in bringing forth some practical perspectives and guidance regarding e-books. The selected works are organized in a way that flows naturally and is easy for readers to navigate. Most contributors of this work, except for one, are from the United Kingdom, so some terminology and usage do sound alien for American readers; but this does not neces-

\section{Index to advertisers}

ACRL Publications

Annual Reviews

Archival Products

Bowker/RCL

Brill cover 4,403

CHOICE Reviews Online 496

Image Access cover 2

MIT Press Journals

407

Palgrave sarily reduce the value of this book to the U.S. audience. Besides, the book offers a good amount of coverage on e-books in academic library settings, which could benefit many academic librarians who have just started to deal with e-books. However, the book fails to touch on a highly controversial but vitally important issue: circulating e-book readers in libraries. Also, though it claims to be the first practical guide of e-books, I would argue that it does not provide the amount of hands-on guidance that I expected. It does a good job in outlining the big picture and giving general directions; but the reader could be better served if the book could nail down some detailed workflows in handling e-books. Overall, this book is a great reference source for library and information professionals who are responsible for building and maintaining an e-book collection; it is also essential background reading for those who are interested in e-books in general.-Ning Han, Mississippi State University Libraries.

\section{The Medieval Book: Glosses from Friends} and Colleagues of Christopher de Hamel. Eds. James H. Marrow, Richard A. Linenthal, and William Noel. Houten, Netherlands: Hes \& De Graaf Publishers, 2010. xxxii +468 p. clothbound, \$95 (ISBN 9879061943709). LC2011-417859.

For librarians and curators involved with collecting, cataloguing, teaching, and researching medieval manuscripts, Christopher de Hamel is a shining star whose erudition and lifetime of work illuminates the far reaches and dark corners of a field that is often full of confusing and seemingly unsolvable problems. Acknowledged by many to be the most gifted and knowledgeable manuscript studies scholar working in the field today, de Hamel's painstaking, creative, and influential work as cataloger, and later Head, of Western Manuscripts at Sotheby's from 1975 to 2000 (where de Hamel estimates he professionally assessed and described over 10,000 manuscripts) and, since 2000, 